\title{
Palladium-Catalyzed Synthesis of Aryl Ketones from Carboxylic Acids and Arylboronic Acids Using EEDQ
}

\author{
Young Bum Kwon, Bo Ram Choi, Seung Hwan Lee, Jin-soo Seo, and Cheol Min Yoon* \\ Department of Advanced Material Chemistry, Korea University, Jochiwon, Choong-nam 339-700, Korea \\ *E-mail: cmyoon@korea.ac.kr \\ Received May 4, 2010, Accepted July 10, 2010
}

Key Words: Aryl ketone, Carboxylic acid, Arylboronic acid, EEDQ, Palladium

Aryl ketones are important structural motifs found in a number of natural and unnatural products of biological and medicinal interest. ${ }^{1}$ A traditional method for the preparation of arylketones is Friedel-Crafts acylation. ${ }^{2}$ However, it has major drawbacks, such as limited regioselectivity, difficulty of regioisomer separation, harsh reaction condition, and incompatibility with other functional groups. ${ }^{2(d)}$ Arylketones can also be prepared by the nucleophilic addition of organometallics such as magnesium, lithium, zinc, copper, boron, tin or cadmium reagents to a variety of carboxylic acid derivatives including thioesters, nitrile, amides, and acid halides. ${ }^{3}$ However, harsh condition and low yields due to the formation of tertiary alcohols as side products are the serious problems. ${ }^{7}$ The recently reported mild methods are palladium-catalyzed cross-coupling reaction of activated carboxylic acid derivatives, for example, acid chlorides, ${ }^{4,7}$ thioesters, ${ }^{5}$ 2-pyridyl esters, ${ }^{6}$ and anhydrides ${ }^{7,8(b)}$ with boronic acids or other organoboranes. These methods are mild, efficient, and regioselective. However, there are several limitations of these methods. The acid derivatives are not commercially available and anhydride is inefficient to use because the half part of carboxylic anhydride is lost as a leaving group. Gooßen and his coworkers reported a palladium-catalyzed synthesis of aryl ketones directly by the reaction of boronic acids with active ester or anhydride of carboxylic acid generated in situ using activating group, such as disuccinimidyl carbonate, pivalic anhydride, or dimethyl dicarbonate. ${ }^{8}$ These approaches give good yields even for sensitive functionalized substrates and save one reaction step in comparison to the standard processes. However, the reagent is expensive, difficult to handle, and generating acid. In addition, the reaction is not efficient and needs specific catalytic systems depending on substrates. Therefore, alternative and complementary approach is demanding. $N$-Ethoxycarbonyl-2-ethoxy-1,2-dihydroquinoline (EEDQ) has been known to be a coupling reagent in the peptide synthesis, ${ }^{9}$ a reagent in the protection of 2-hydroxycarboxylic acid, ${ }^{10}$ and a substrate for the synthesis of dihydroquinoline derivatives. ${ }^{11}$ The key intermediates in the reactions are reported to be a mixed anhydride generated in situ. It occurs to us that the mixed

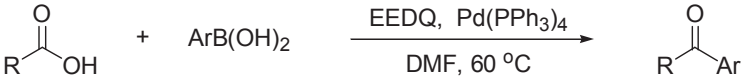

$$
\begin{aligned}
& 12 \\
& 3
\end{aligned}
$$

anhydride generated in situ might be used for the synthesis of aryl ketone via the palladium catalyzed cross coupling reaction of carboxylic acid with boronic acid. Here, we report an efficient coupling reaction of carboxylic acids with aryl boronic acids in DMF in the presence of EEDQ, $\mathrm{Pd}\left(\mathrm{PPh}_{3}\right)_{4}$, and water at $60{ }^{\circ} \mathrm{C}$ to give the corresponding aryl ketones (Scheme 1). Our method might be a nice alternative to the methods developed recently.

The coupling reaction of benzoic acid with benzeneboronic acid in the presence of EEDQ and 2.5 equiv. of water ${ }^{8 c}$ was conducted using palladiums such as $\mathrm{Pd}(\mathrm{OAc})_{2}, \mathrm{Pd}_{2}(\mathrm{dba})_{3} \cdot \mathrm{CH}_{3} \mathrm{Cl}$, $\mathrm{Pd}(\mathrm{acac})_{2}, \mathrm{Pd}\left(\mathrm{PPh}_{3}\right)_{4}$ and phosphine ligands such as $\mathrm{PPh}_{3}$, (o-tolyl) ${ }_{3} \mathrm{P}$, (furyl $)_{3} \mathrm{P}, \mathrm{BINAP}$, dppf in THF for $15 \mathrm{~h}$ and the results are listed in Table 1 (entries 1-11). $\mathrm{Pd}\left(\mathrm{PPh}_{3}\right)_{4}$ was identified to be the best palladium catalyst in the coupling reaction and 2.5 equiv. of water is necessary for the efficient reaction (entries 2 and 11). The reaction was examined in the other solvents such as DMF, acetonitrile, and dioxane. DMF and acetonitrile were proved to be the most effective solvents in the

\begin{tabular}{|c|c|c|c|}
\hline Entry & Palladium (Pd) / Ligand & Solvent & Yield $(\%)^{b}$ \\
\hline 1 & $\mathrm{Pd}(\mathrm{OAc})_{2} / \mathrm{PPh}_{3}$ & THF & 63 \\
\hline $2^{c}$ & $\mathrm{Pd}(\mathrm{OAc})_{2} / \mathrm{PPh}_{3}$ & THF & 40 \\
\hline 3 & $\mathrm{Pd}(\mathrm{OAc})_{2} /(o \text {-tolyl })_{3} \mathrm{P}$ & THF & 13 \\
\hline 4 & $\mathrm{Pd}(\mathrm{OAc})_{2} /(\text { furyl })_{3} \mathrm{P}$ & THF & 33 \\
\hline 5 & $\mathrm{Pd}(\mathrm{OAc})_{2} / \mathrm{P}(\mathrm{OPh})_{3}$ & THF & 27 \\
\hline $6^{d}$ & $\mathrm{Pd}(\mathrm{OAc})_{2} / \mathrm{BINAP}$ & THF & 10 \\
\hline $7^{d}$ & $\mathrm{Pd}(\mathrm{OAc})_{2} / \mathrm{dppf}$ & THF & trace \\
\hline 8 & $\mathrm{Pd}_{2}(\mathrm{dba})_{3} \cdot \mathrm{CH}_{3} \mathrm{Cl} / \mathrm{PPh}_{3}$ & THF & 14 \\
\hline 9 & $\mathrm{Pd}(\mathrm{acac})_{2} / \mathrm{PPh}_{3}$ & THF & 7 \\
\hline 10 & $\mathrm{Pd}\left(\mathrm{PPh}_{3}\right)_{4}$ & THF & 73 \\
\hline $11^{c}$ & $\mathrm{Pd}\left(\mathrm{PPh}_{3}\right)_{4}$ & THF & 47 \\
\hline 12 & $\mathrm{Pd}\left(\mathrm{PPh}_{3}\right)_{4}$ & Dioxane & 43 \\
\hline 13 & $\mathrm{Pd}\left(\mathrm{PPh}_{3}\right)_{4}$ & $\mathrm{CH}_{3} \mathrm{CN}$ & 90 \\
\hline 14 & $\mathrm{Pd}\left(\mathrm{PPh}_{3}\right)_{4}$ & DMF & 93 \\
\hline 15 & $\mathrm{Pd}\left(\mathrm{PPh}_{3}\right)_{4}$ (without EEDQ) & DMF & No reaction \\
\hline
\end{tabular}

Table 1. The reaction of benzoic acid and benzeneboronic acid at $60^{\circ} \mathrm{C}$

${ }^{a}$ Reaction conditions: benzoic acid $(100 \mathrm{mg}, 0.82 \mathrm{mmol})$, benzeneboronic acid (120 mg, $0.98 \mathrm{mmol}), \operatorname{EEDQ}(247 \mathrm{mg}, 1.23 \mathrm{mmol}), \mathrm{H}_{2} \mathrm{O}(37 \mu \mathrm{L}, 2.05$ $\mathrm{mmol})$, palladium catalyst $(3.0 \mathrm{~mol} \%)$, ligand $(6.6 \mathrm{~mol} \%)$, solvent $(1 \mathrm{~mL})$, $15 \mathrm{~h}, 60{ }^{\circ} \mathrm{C}$. ${ }^{b}$ Isolated yield. ${ }^{c}$ Water was not added. ${ }^{d} 3.3 \mathrm{~mol} \%$ ligand. 
Table 2. Reaction ${ }^{a}$ of carboxylic acids with arylboronic acids under the optimum condition

\begin{tabular}{|c|c|c|c|c|c|}
\hline Entry & $\mathrm{R}$ & $\mathrm{Ar}$ & Ketones $^{b}$ & Product & Yield $^{c}(\%)$ \\
\hline 1 & $4-\mathrm{MeOC}_{6} \mathrm{H}_{4}$ & $\mathrm{Ph}$ & 4- $\mathrm{MeOC}_{6} \mathrm{H}_{4} \mathrm{COPh}$ & $3 \mathbf{a}$ & $84^{d}$ \\
\hline 2 & $4-\mathrm{MeC}_{6} \mathrm{H}_{4}$ & $\mathrm{Ph}$ & $4-\mathrm{MeC}_{6} \mathrm{H}_{4} \mathrm{COPh}$ & $3 \mathbf{b}$ & 82 \\
\hline 3 & 2,3-diMeC ${ }_{6} \mathrm{H}_{3}$ & $\mathrm{Ph}$ & 2,3-diMeC ${ }_{6} \mathrm{H}_{3} \mathrm{COPh}$ & $3 \mathbf{c}$ & $83^{e}$ \\
\hline 4 & $2-\mathrm{Cl} \mathrm{C}_{6} \mathrm{H}_{4}$ & $\mathrm{Ph}$ & $2-\mathrm{ClC}_{6} \mathrm{H}_{4} \mathrm{COPh}$ & 3d & 84 \\
\hline 5 & $3-\mathrm{Cl} \mathrm{C} \mathrm{H}_{4}$ & $\mathrm{Ph}$ & $3-\mathrm{ClC}_{6} \mathrm{H}_{4} \mathrm{COPh}$ & $3 e$ & 84 \\
\hline 6 & 4-Cl-2-MeOC ${ }_{6} \mathrm{H}_{3}$ & $\mathrm{Ph}$ & 4-Cl-2- $\mathrm{MeOC}_{6} \mathrm{H}_{4} \mathrm{COPh}$ & $3 f$ & $73^{e}$ \\
\hline 7 & 1-naphthyl & $\mathrm{Ph}$ & 1-naphthyl-COPh & $3 g$ & 82 \\
\hline 8 & $\mathrm{CH}_{3}\left(\mathrm{CH}_{2}\right)_{4}$ & $\mathrm{Ph}$ & $\mathrm{CH}_{3}\left(\mathrm{CH}_{2}\right)_{4}-\mathrm{COPh}$ & $3 \mathbf{h}$ & $77^{f}$ \\
\hline 9 & $\mathrm{CH}_{3} \mathrm{CH}_{2}$ & $\mathrm{Ph}$ & $\mathrm{CH}_{3} \mathrm{CH}_{2}-\mathrm{COPh}$ & $3 \mathbf{i}$ & $79^{f}$ \\
\hline 10 & $\mathrm{Ph}$ & $4-\mathrm{MeOC}_{6} \mathrm{H}_{4}$ & 4- $\mathrm{MeOC}_{6} \mathrm{H}_{4} \mathrm{COPh}$ & $3 \mathbf{j}$ & 96 \\
\hline 11 & 4- $\mathrm{MeC}_{6} \mathrm{H}_{4}$ & $4-\mathrm{MeOC}_{6} \mathrm{H}_{4}$ & 4-MeOC ${ }_{6} \mathrm{H}_{4} \mathrm{COPh}-4-\mathrm{Me}$ & $3 \mathbf{k}$ & $90^{d}$ \\
\hline 12 & $2-\mathrm{Cl} \mathrm{C}_{6} \mathrm{H}_{4}$ & $4-\mathrm{MeOC}_{6} \mathrm{H}_{4}$ & $4-\mathrm{MeOC}_{6} \mathrm{H}_{4} \mathrm{COPh}-2-\mathrm{Cl}$ & 31 & 79 \\
\hline 13 & $3-\mathrm{Cl} \mathrm{C}_{6} \mathrm{H}_{4}$ & $4-\mathrm{MeOC}_{6} \mathrm{H}_{4}$ & $4-\mathrm{MeOC}_{6} \mathrm{H}_{4} \mathrm{COPh}-3-\mathrm{Cl}$ & $3 \mathrm{~m}$ & 97 \\
\hline 14 & $\mathrm{Ph}$ & $4-\mathrm{MeC}_{6} \mathrm{H}_{4}$ & 4- $\mathrm{MeOC}_{6} \mathrm{H}_{4} \mathrm{COPh}$ & $3 n$ & 99 \\
\hline 15 & $\mathrm{Ph}$ & $4-\mathrm{ClC}_{6} \mathrm{H}_{4}$ & $4-\mathrm{ClC}_{6} \mathrm{H}_{4} \mathrm{COPh}$ & 30 & 97 \\
\hline 16 & $\mathrm{Ph}$ & 2-thienyl & 2-thienyl-COPh & $3 p$ & 79 \\
\hline
\end{tabular}

${ }^{a}$ Conditions: $1.0 \mathrm{mmol}$ carboxylic acid, 1.2 equiv. arylboronic acid, 1.5 equiv. EEDQ, 2.5 equiv. $\left.\mathrm{H}_{2} \mathrm{O}, 3.0 \mathrm{~mol} \% \mathrm{Pd}_{(\mathrm{PPh}}\right)_{4}, \mathrm{DMF}(1 \mathrm{~mL}), 60{ }^{\circ} \mathrm{C}, 15 \mathrm{~h}$. ${ }^{b}$ Spectroscopic data of all products were consistent with those of corresponding known compounds. ${ }^{c}$ Isolated yield. ${ }^{d}$ Reaction time for $30 \mathrm{~h} .{ }^{e}$ at $80{ }^{\circ} \mathrm{C} . f_{2.5}$ equiv. benzeneboronic acid.

coupling reaction. The mixed anhydride of carboxylic acid was detected by TLC during the reaction and the ethyl ester of benzoic acid as a side product was not observed under the reaction condition.

To investigate the scope and limitations, the reaction of a variety of carboxylic acids with a variety of boronic acids in $\mathrm{DMF}^{12}$ at $60{ }^{\circ} \mathrm{C}$ were studied and the results are listed in Table 2. Generally, the reactions work well with both electron rich and poor carboxylic acid as well as electron rich and poor boronic acid. The benzoic acid with substituent at ortho position is less reactive, probably resulting from steric crowdness and therefore the reaction was conducted at $80{ }^{\circ} \mathrm{C}$ to give the corresponding ketones in high yields (entries 3 and 6). Excess amount of boronic acid in the reaction of hexanoic and propanoic acids has been used due to the formation of large amount of biphenyl as a side product from the homocoupling of arylboronic acid, probably resulting from the low reactivity of mixed anhydride of hexanoic and propanoic acids (entries 8 and 9).

The plausible mechanism is shown in Scheme 2 based on the reported one. ${ }^{13}$ The coupling reaction is proceeded through a mixed anhydride $\mathbf{5}$ formed in situ via adduct $\mathbf{4}$ generated from the reaction of carboxylic acid with EEDQ. The mixed anhydride $\mathbf{5}$ is oxidatively added to palladium (0) generating an acylpalladium carbonate complex $\mathbf{6}$. It might be decarboxylated and transmetallated with arylboronic acid to give palladium complex $\mathbf{8}$ which was isomerized to $c i$ isomer and reductively eliminated to give a coupling product $\mathbf{3}$.

Carboxylic acid derivatives are successfully coupled with arylboronic acids in the presence of EEDQ as an activating reagents and $\mathrm{Pd}\left(\mathrm{PPh}_{3}\right)_{4}$ as a catalyst in 2 equiv. $\mathrm{H}_{2} \mathrm{O}$ and DMF at $60{ }^{\circ} \mathrm{C}$ to give diarylketone in high to excellent yields. Our catalytic coupling system is general, simple and efficient. Therefore, our method might be a nice alternative to that developed by others.

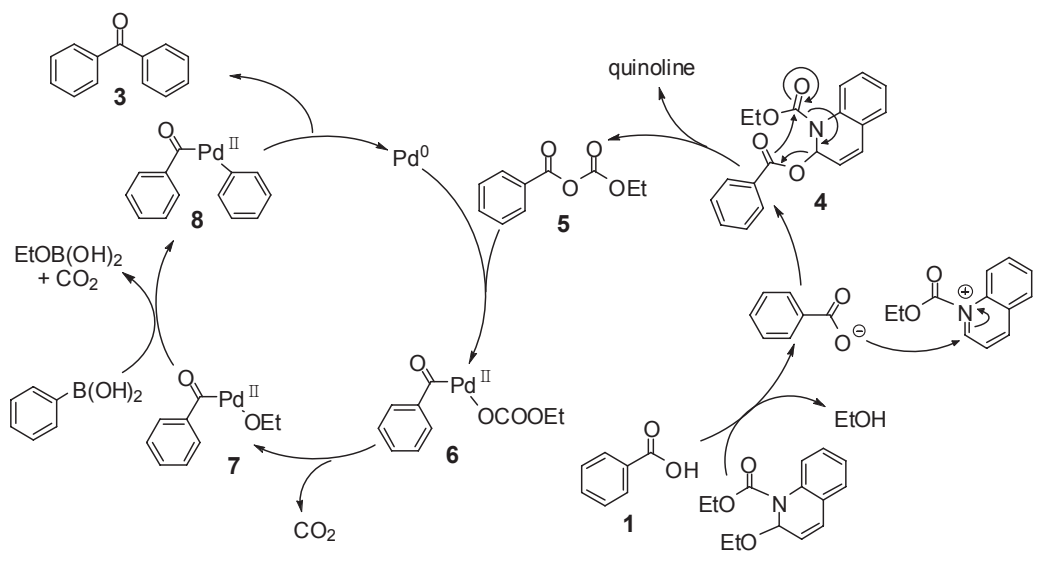

Scheme 2 


\section{Experimental Section}

A typical procedure of the synthesis of 4-methoxybenzophenone (3a). ${ }^{7(a)}$ To a solution of 4-methoxybenzoic acid (100 $\mathrm{mg}, 0.66 \mathrm{mmol})$, EEDQ (244 $\mathrm{mg}, 0.99 \mathrm{mmol})$ and $\mathrm{Pd}\left(\mathrm{PPh}_{3}\right)_{4}$ $(23 \mathrm{mg}, 0.02 \mathrm{mmol})$ in DMF $(1 \mathrm{~mL})$ and water $(30 \mu \mathrm{L}, 1.66$ $\mathrm{mmol}$ ) in a $5 \mathrm{~mL}$ reaction vessel was added phenylboronic acid (96 $\mathrm{mg}, 0.79 \mathrm{mmol}$ ) and the resulting solution was purged with argon. The reaction mixture was stirred for $15 \mathrm{~h}$ at $60{ }^{\circ} \mathrm{C}$ and the reaction was monitored by TLC (ethyl acetate $: n$-hexane $=1: 10)$. After the reaction, the mixture was quenched with water $(5 \mathrm{~mL})$, and the aqueous solution was extracted with ethyl acetate $(5 \mathrm{~mL})$ three times. The combined ethyl acetate phases were concentrated and further purification of the product was achieved by flash column chromatography on silica gel (ethyl acetate : $n$-hexane $=1: 10$ ) to give a 4-methoxybenzophenone 3a $(84 \%)$ as a white solid. ${ }^{1} \mathrm{H}$ NMR $\left(\mathrm{CDCl}_{3}, 300\right.$ $\mathrm{MHz}) \delta 7.83(\mathrm{~d}, J=8.7 \mathrm{~Hz}, 2 \mathrm{H}), 7.76(\mathrm{~d}, J=6.9 \mathrm{~Hz}, 2 \mathrm{H}), 7.57$ (t, $J=7.2 \mathrm{~Hz}, 1 \mathrm{H}), 7.47$ (dd, $J=6.9$ and $7.2 \mathrm{~Hz}, 2 \mathrm{H}), 6.97$ (d, $J=8.7 \mathrm{~Hz}, 2 \mathrm{H}), 3.89$ (s, 3H).

Acknowledgments. This work was supported by Korea University.

\section{References}

1. (a) Dieter, R. K. Tetrahedron 1999, 55, 4177. (b) Zhang, Y. D.; Rovis, T. J. Am. Chem. Soc. 2004, 126, 15964. (c) Hatano, B.; Kadokawa, J. I.; Tagaya, H. Tetrahedron Lett. 2002, 43, 5859.

2. (a) Shi, M.; Wu, L.; Lu, J.-M. Tetrahedron 2008, 64, 3315. (b) Gmouh, S.; Yang, H.; Vaultier, M. Org. Lett. 2003, 5, 2219. (c) Fillion, E.; Fishlock, D.; Wilsily, A.; Goll, J. M. J. Org. Chem. 2005, 70, 1316. (d) Ruan, J.; Saidi, O.; Iggo, J. A.; Xiao, J. J. Am. Chem. Soc. 2008, 130, 10510. References cited therein.
3. (a) Labadie, J. W.; Stille, J. K. J. Am. Chem. Soc. 1983, 105, 669. (b) Arisawa, M.; Torisawa, Y.; Kawahara, M.; Yamanaka, M.; Nishida, A.; Nakagawa, M. J. Org. Chem. 1997, 62, 4327. (c) Wang, X.-J.; Zhang, L.; Sun, X.; Xu, Y.; Krishnamurthy, D.; Senanayake, C. H. Org. Lett. 2005, 7, 5593. (d) Wang, D. H.; Zhang, Z. Z. Org. Lett. 2003, 5, 4645.

4. (a) Haddach, M.; McCarthy, J. R. Tetrahedron Lett. 1999, 40, 3109. (b) Urawa, Y.; Ogura, K. Tetrahedron Lett. 2003, 44, 271. (c) Bandgar, B. P.; Patil, A. V. Tetrahedron Lett. 2005, 46, 7627. (d) Chen, H.; Deng, M. Z. Org. Lett. 2000, 2, 1649. (e) Bumagin, N. A.; Korolev, D. N. Tetrahedron Lett. 1999, 40, 3057.

5. (a) Liebeskind, L. S.; Srogl, J. J. Am. Chem. Soc. 2000, 122, 11260. (b) Yu, Y.; Liebeskind, L. S. J. Org. Chem. 2004, 69, 3554

6. Tatamidani, H.; Kakiuchi, F.; Chatani, N. Org. Lett. 2004, 6, 3597.

7. (a) Xin, B.; Zhang, Y.; Cheng, K. Synthesis 2007, 1970. (b) Xin, B.; Zhang, Y.; Cheng, K. J. Org. Chem. 2006, 71, 5725.

8. (a) Gooßen, L. J.; Ghosh, K. Eur. J. Org. Chem. 2002, 19, 3254. (b) Gooßen, L. J.; Ghosh, K. Chem. Commun. 2001, 2084. (c) Gooßen, L. J.; Winkel, L.; Döhring, A.; Ghosh, K.; Paetzold, J. Synlett 2002, 1237. (d) Gooßen, L. J.; Ghosh, K. Angew. Chem. Int. Ed. 2001, 40, 3458.

9. (a) Belleau, B.; Malek, G. J. Am. Chem. Soc. 1968, 90, 1651. (b) Belleau, B.; Martel, R. R.; Lacasse, G.; Menard, M.; Weinberg, N. L.; Perron, Y. G. J. Am. Chem. Soc. 1968, 90, 823. (c) Brown, J.; Williams, R. E. Can. J. Chem. 1971, 49, 3765.

10. Hyun, M. H.; Kang, M. H.; Han, S. C. Tetrahedron Lett. 1999 , $40,3435$.

11. (a) Lee, J. H.; Kweon, J. S.; Yoon, C. M. Tetrahedron Lett. 2002, 43, 5771. (b) Chang, Y. M.; Lee, S. H.; Nam, M. H.; Cho, M. Y.; Park, Y. S.; Yoon, C. M. Tetrahedron Lett. 2005, 46, 3053. (c) Yamaoka, Y.; Miyabe, H.; Takemoto, Y. J. Am. Chem. Soc. 2007, $129,6686$.

12. Because DMF was identified to be better than acetonitrile in the reaction of 4-methoxybenzoic acid and methylbenzoic acid with phenylboronic acid, all the reactions were performed in DMF.

13. (a) Kakino, R.; Narahashi, H.; Shimizu, I.; Yamamoto, A. Chem. Lett. 2001, 1242. (b) Kakino, R.; Narahashi, H.; Shimizu, I.; Yamamoto, A. Bull. Chem. Soc. Jpn. 2002, 75, 137. (c) Amatore, C.; Jutand, A. Acc. Chem. Res. 2000, 33, 314. 